\title{
Comparative functional characteristics of DMSP lyases extracted from polar and temperate Phaeocystis species
}

\author{
Bidyut R. Mohapatra ${ }^{1,2}$, Alison N. Rellinger ${ }^{1,2}$, David J. Kieber ${ }^{3}$, Ronald P. Kiene ${ }^{1,2, *}$ \\ ${ }^{1}$ Department of Marine Sciences, University of South Alabama, Mobile, Alabama 36688, USA \\ ${ }^{2}$ Dauphin Island Sea Lab, Dauphin Island, Alabama 36528, USA \\ ${ }^{3}$ Department of Chemistry, College of Environmental Science and Forestry, State University of New York, 1 Forestry Drive, \\ Syracuse, New York 13210, USA
}

\begin{abstract}
Members of the marine phytoplankton genus Phaeocystis (Prymnesiophyceae) produce large amounts of the intracellular osmolyte DMSP and they are known to also produce lyase enzymes that cleave DMSP into the biogeochemically important trace gas DMS. The functional characteristics of DMSP lyase activity in Phaeocystis spp. are not well known. We characterized DMSP lyase activity in extracts from 2 ecologically important species from this genus, the mesophile $P$. globosa (strain CCMP629) and the psychrophile $P$. antarctica (strain CCMP1374). Results from whole cell extracts showed that both algal species were potent producers of DMSP lyase, with Michaelis-Menten constant $\left(K_{\mathrm{m}}\right)$ and maximum reaction velocity $\left(V_{\max }\right)$ values of $1.77 \mathrm{mM}$ and $17.3 \mathrm{nmol} \mathrm{DMS} \mathrm{min}^{-1} \mathrm{mg} \mathrm{protein}^{-1}$, respectively, for P. globosa, and $2.31 \mathrm{mM}$ and $28.2 \mathrm{nmol}$ DMS $\mathrm{min}^{-1} \mathrm{mg}$ protein ${ }^{-1}$, respectively, for $P$. antarctica. The optimal DMSP lyase activity was recorded at $\mathrm{pH} 4$ and $30^{\circ} \mathrm{C}$ for $P$. globosa, and at $\mathrm{pH} 5$ and $20^{\circ} \mathrm{C}$ for $P$. antarctica. The half-life of the DMSP lyase of $P$. globosa was 210 min at $25^{\circ} \mathrm{C}$, which was longer than that of the $P$. antarctica enzyme (61.9 min). First-order kinetic analysis of DMSP lyase thermal denaturation demonstrated that the activation energy, free energy, enthalpy and entropy of denaturation in $P$. antarctica extracts were lower than for $P$. globosa extracts, confirming that the $P$. antarctica DMSP lyase was more thermolabile than the lyase from the temperate strain. Inhibitor tests with metals, a chelator (EDTA) and a serine binding agent (PMSF) suggested that the DMSP lyases from both Phaeocystis species were metalloenzymes with serine and sulfhydryl groups at the active site. The acidic $\mathrm{pH}$ optima for the Phaeocystis strains are consistent with findings from other Prymnesiophyceae, and we speculate that this may reflect adaptation to an acidic sub-cellular location for the DMSP lyase.
\end{abstract}

KEY WORDS: Dimethylsulfide · Dimethylsulfoniopropionate · DMSP · DMSP lyase · Prymnesiophyte · Psychrophile

Resale or republication not permitted without written consent of the publisher

\section{INTRODUCTION}

DMSP is a secondary metabolite synthesized by a wide variety of marine algae (reviewed in Keller et al. 1989). DMSP has been linked to different physiological functions, such as osmoregulation (Dickson \& Kirst 1987), cryoprotection (Kirst et al. 1991, Karsten et al. 1996), oxidative stress protection (Sunda et al. 2002), methyl donor (Ishida 1968) and overflow metabolite for excess reducing power during photosynthesis (Stefels 2000). DMSP degradation in marine environments occurs via 2 different biochemical pathways (reviewed in Curson et al. 2011, Moran et al. 2012). In the first pathway, the DMSP is cleaved 
via the enzyme DMSP demethylase to 3-(methylmercapto)propionic acid (MMPA). In a subsequent reaction, MMPA either undergoes demethylation to form 3-mercaptopropionic acid and/or demethiolation to form methanethiol (Reisch et al. 2011). In the second pathway, DMSP lyase (EC 4.4.1.3) catalyzes the lysis of DMSP into dimethylsulfide (DMS), acrylate and a proton. There is worldwide interest in evaluating the biochemical and molecular mechanisms involved in the regulation of enzymatic cleavage of DMSP to DMS because DMS is an important component of the global sulfur cycle and a potential climate-active trace gas. DMS is supersaturated in all surface ocean waters and, once transferred to the atmosphere, it rapidly oxidizes to dimethylsulfoxide, methanesulfonate (MSA) or sulfate. Sulfur-containing, acidic aerosols derived from these compounds can affect the Earth's climate system by scattering incoming sunlight and contributing to the population of aerosol particles that act as cloud condensation nuclei (Charlson et al. 1987, Simó 2001).

DMSP lyases are the key enzymes responsible for the biogenic production of DMS in marine waters. They have been found in marine algae, including phytoplankton (Steinke et al. 1996, 1998), and in a variety of different bacteria (de Souza \& Yoch 1995a) in which 6 different DMSP lyase proteins (DddD, DddL, DddP, DddQ, DddW and DddY) have been identified (Todd et al. 2007, 2009, 2011, 2012, Curson et al. 2008, 2011, Kirkwood et al. 2010). All these proteins except DddD catalyze cleavage of DMSP into acrylate and DMS. The DddD protein produces 3-hydoxypropionate instead of acrylate. Most of the genes encoding bacterial DMSP lyases are prone to horizontal gene transfers, and in the case of $d d d P$, the gene has been subjected to interdomain horizontal gene transfer between bacteria and Ascomycete fungi (Todd et al. 2009). While DMSP lyases from bacteria have been relatively well characterized at the genetic level, much less is known about phytoplankton DMSP lyases. Published studies of phytoplankton DMSP lyases have shown that their occurrence and properties are often species- and strain-specific (Steinke et al. 1996, 1998, Niki et al. 2000, Yost \& Mitchelmore 2009, Franklin et al. 2010), but few species have been well characterized.

Phaeocystis (Prymnesiophyceae) is a cosmopolitan group of marine phytoplankton that comprises 6 different species, including colony-forming P. globosa, P. antarctica and P. pouchetii, and unicellular P. cordata, P. jahnii and P. scrobiculata (Zingone et al. 1999). Colonial Phaeocystis species form massive blooms in both temperate and polar regions and substantially impact the yield of commercially important marine products (Schoemann et al. 2005). Phaeocystis blooms play a major role in the biogeochemical cycle of carbon and sulfur by fixing a large amount of carbon dioxide and by producing high concentrations of DMSP and DMS (Stefels \& van Leeuwe 1998, van Duyl et al. 1998, Arrigo et al. 1999, DiTullio et al. 2003), and by providing an important substrate for bacterial carbon demand (Rellinger et al. 2009).

Despite the importance of Phaeocystis species in global biogeochemical cycles, climate dynamics and coastal fisheries, very few studies have been performed to characterize the DMSP lyase activity of bloom-forming Phaeocystis (Stefels \& van Boekel 1993, Stefels et al. 1995, Stefels \& Dijkhuizen 1996). The objective of the present study was to compare the functional (i.e. DMSP cleaving) properties of DMSP lyase extracted from 2 different, but closely related Phaeocystis species: the mesophile P. globosa and the psychrophile $P$. antarctica. Our findings define the significant properties of DMSP lyase in these ecologically important species that will be useful in future investigations into the ecophysiology of DMSP cleavage in temperate and polar regions of the world oceans.

\section{MATERIALS AND METHODS}

\section{Phaeocystis culture}

P. globosa (CCMP 629), originally isolated from the subtropical North Atlantic $\left(\sim 23^{\circ} \mathrm{N}, 75^{\circ} \mathrm{W}\right.$; typical temperature range 20 to $30^{\circ} \mathrm{C}$ ) and $P$. antarctica (CCMP $1374)$, isolated from the Ross Sea $\left(77.8^{\circ} \mathrm{S}, 163^{\circ} \mathrm{E} ;-1.8\right.$ to $3.0^{\circ} \mathrm{C}$ ), were obtained from The Provasoli-Guillard Center for the Cultivation of Marine Phytoplankton (CCMP, Maine, USA; now the National Center for Marine Algae and Microbiota [NCMA]). The batch cultivation of the algal species was carried out in duplicate in $600 \mathrm{ml}$ polycarbonate tissue culture flasks with $0.2 \mu \mathrm{m}$ vent caps (Corning), containing $500 \mathrm{ml} \mathrm{f} / 2$ medium (Guillard 1975). The incubation temperature was 20 and $1^{\circ} \mathrm{C}$ for P. globosa and $P$. antarctica, respectively, and cultures were grown under fluorescent light $\left(133 \mu\right.$ Einstein $\left.\mathrm{m}^{-2} \mathrm{~s}^{-1}\right)$ with a 12:12 h light:dark cycle. Algal cultures were harvested in the exponential growth phase by centrifugation at $3000 \times g\left(4^{\circ} \mathrm{C}\right)$ for $15 \mathrm{~min}$. The supernatant fluid was discarded and the resulting pellets were used for the extraction of DMSP lyase. Chlorophyll (chl) a concentrations at the time of harvest were 
$0.56 \pm 0.05 \mu \mathrm{g} \mathrm{ml}^{-1}$ for P. globosa and $0.47 \pm 0.03 \mu \mathrm{g}$ $\mathrm{ml}^{-1}$ for $P$. antarctica. The chl a concentration was determined fluorometrically as described previously (Parsons et al. 1984). Both phytoplankton species were predominantly in the colonial cell form at the time of harvest.

\section{DMSP lyase extraction}

The extraction of DMSP lyase was performed as reported previously with some modifications (Harada \& Kiene 2012). Briefly, algal pellets from each flask were resuspended in $5 \mathrm{ml}$ of ice-cold $200 \mathrm{mM}$ Tris$\mathrm{HCl}$ buffer ( $\mathrm{pH} 7.5)$ containing $500 \mathrm{mM} \mathrm{NaCl}, 2 \mathrm{mM}$ dithiothreitol (DTT) and $0.1 \%(\mathrm{v} / \mathrm{v})$ Triton X-100, followed by vigorous vortex mixing and centrifugation at $3500 \times g\left(4^{\circ} \mathrm{C}\right)$ for $15 \mathrm{~min}$. The supernatant was collected and concentrated using an Amicon Ultra 10000 MWCO centrifugal filter device (Millipore). As the standard deviation of the DMSP lyase activities of the replicate cultures of each algal species were $<10 \%$ of the mean values, the concentrated fractions of each algal species were pooled together. The pooled fractions were diluted with $10 \mathrm{ml}$ of $25 \mathrm{mM}$ Tris-HCl buffer ( $\mathrm{pH} 7.5)$, divided into $0.5 \mathrm{ml}$ aliquots and stored at $-20^{\circ} \mathrm{C}$. The aliquots were used for characterization studies. There was no loss in enzyme activity detected during the 4 wk period during which characterization studies were performed.

\section{DMSP lyase assay}

DMSP lyase activity was defined as the rate of conversion of DMSP to DMS. DMSP lyase activity was assessed at 30 and $20^{\circ} \mathrm{C}$ for P. globosa and P. antarctica, respectively, in sealed $10 \mathrm{ml}$ serum vials containing a standard assay mixture of $146 \mu l$ assay buffer (200 $\mathrm{mM}$ phosphate-citrate buffer adjusted to pH 4 for P. globosa and pH 5 for P. antarctica) and $50 \mu \mathrm{l}$ of enzyme $\left(\sim 120 \mu \mathrm{g}\right.$ protein $\left.\mathrm{ml}^{-1}\right)$. The reaction was started by the addition of $4 \mu \mathrm{l}$ of $250 \mathrm{mM}$ DMSP. $\mathrm{HCl}$ aqueous solution (5 mM final concentration), and the resulting DMS in the headspace of the vial was quantified in a $30 \mathrm{~min}$ period using a gas chromatograph equipped with a flame photometric detector (Steinke et al. 2000, Harada et al. 2004). Appropriate blanks were also prepared to correct for abiotic DMS production from DMSP hydrolysis. For these controls, $50 \mu \mathrm{l}$ heat-treated enzyme preparation $\left(95^{\circ} \mathrm{C}\right.$ for $30 \mathrm{~min}$ in a sealed tube, and rapidly cooled to $4^{\circ} \mathrm{C}$ ) was added in place of the original enzyme solution. All assays were repeated twice and data are presented as mean $\pm \mathrm{SD}$. One unit of specific enzyme activity (U) was defined as $1 \mathrm{nmol}$ of DMS produced $\mathrm{min}^{-1} \mathrm{mg}$ protein ${ }^{-1}$. Protein was quantified using the Bio-Rad Bradford protein assay kit with bovine serum albumin as the standard.

\section{Contribution of bacterial DMSP lyase}

A subsample $(0.5 \mathrm{ml})$ of each Phaeocystis culture was filtered through a Whatman GF/C filter $(25 \mathrm{~mm}$ diameter, $1.2 \mu \mathrm{m}$ nominal pore size) with gentle vacuum, followed by washing with $0.5 \mathrm{ml} / 2$ medium to rinse through bacteria. The resulting filtrate was filtered again through a $0.22 \mu \mathrm{m}$ pore size polycarbonate filter (25 $\mathrm{mm}$ diameter, Millipore) using gentle filtration. Both GF/C and polycarbonate filters were placed into separate $14 \mathrm{ml}$ serum vials containing $980 \mu \mathrm{l}$ of assay buffer $(200 \mathrm{mM}$ phosphate-citrate buffer adjusted to $\mathrm{pH} 4$ for $P$. globosa and $\mathrm{pH} 5$ for $P$. antarctica) supplemented with $500 \mathrm{mM} \mathrm{NaCl}, 2 \mathrm{mM}$ DTT and $0.1 \%(\mathrm{v} / \mathrm{v})$ Triton X-100. The reaction was started by the addition of $20 \mu \mathrm{l}$ of $250 \mathrm{mM}$ DMSP.HCl aqueous solution (5 $\mathrm{mM}$ final concentration), and the resulting DMS in the headspace of the vial was quantified as described in the DMSP lyase assay section. The abiotic corrections of DMS were made in a similar fashion with sterile $\mathrm{f} / 2$ medium. Bacterial abundance in the GF/C filtrate was quantified using DAPI staining as described previously (Porter \& Feig 1980).

\section{DMSP lyase: $\mathrm{pH}$ and temperature dependence}

To determine the optimum $\mathrm{pH}$ for DMSP lyase activity in Phaeocystis globosa and P. antarctica extracts, the enzyme assay was performed with buffers of different $\mathrm{pH}$ added to the assay mixture: $200 \mathrm{mM}$ phosphate-citrate ( $\mathrm{pH} 3$ to 6), $200 \mathrm{mM}$ Tris- $\mathrm{HCl}$ (pH 7, 7.5 and 8) or $200 \mathrm{mM}$ borate (pH 9 and 10). The temperature dependence of lyase activity was assayed from 5 to $50^{\circ} \mathrm{C}$ at $5^{\circ} \mathrm{C}$ increments. We also carried out $\mathrm{pH}$ and thermal stability studies in which the enzyme was exposed to a non-optimal $\mathrm{pH}$ (or temperature in a separate experiment) and then returned to the standard condition $\left(\mathrm{pH} 4\right.$ and $30^{\circ} \mathrm{C}$ for P. globosa, and $\mathrm{pH} 5$ and $20^{\circ} \mathrm{C}$ for $P$. antarctica). The $\mathrm{pH}$ stability tests were carried out by pre-incubation of the DMSP lyase solution at $20^{\circ} \mathrm{C}$ for $P$. antarctica or $25^{\circ} \mathrm{C}$ for $P$. globosa in one of the above-mentioned buffers at different pHs ranging from 3 to 10 for 
$15 \mathrm{~min}$. The reaction mixture was then returned to pH 4 and 5 for P. globosa and P. antarctica, respectively, and the DMSP lyase activity was assayed. For the temperature stability tests, lyase preparations were pre-incubated for $30 \mathrm{~min}$ at different temperatures between 5 and $45^{\circ} \mathrm{C}$ (with $5^{\circ} \mathrm{C}$ increments), before the residual enzyme activity was assayed at optimum temperatures, as described in the DMSP lyase assay section.

\section{Determination of kinetic constants}

To determine the Michaelis-Menten constant $\left(K_{\mathrm{m}}\right)$ and maximum reaction velocity $\left(V_{\max }\right)$ for DMSP lyase extracted from the 2 different Phaeocystis species, the enzyme activity was measured as described in the DMSP lyase assay section by using DMSP substrate at different concentrations $(0.1,0.5,1,2.5,5$, $7.5,10,20 \mathrm{mM}$ ). The values of $K_{\mathrm{m}}$ and $V_{\max }$ were determined with Eadie-Hofstee plots, with $V_{\text {max }}$ normalized to protein.

\section{Effect of $\mathrm{NaCl}$}

The effect of $\mathrm{NaCl}$ on DMSP lyase activity for both algal species was examined by adding aqueous $\mathrm{NaCl}$ (final added concentrations of 0.086 to $0.86 \mathrm{M}$ in $0.086 \mathrm{M}$ increments) to the assay buffer (200 mM phosphate-citrate $\mathrm{pH} 4$ buffer for Phaeocystis globosa and pH 5 buffer for $P$. antarctica). Then $50 \mu \mathrm{l}$ of enzyme extract and $4 \mu \mathrm{l}$ of DMSP were added to $146 \mu$ l of the ionic-strength-adjusted buffer solution, and the enzyme activity assayed as described in the DMSP lyase assay section.

\section{Effect of DMSP analogs, metal ions and organic chemicals}

The effect of different DMSP analogs (2-methyl DMSP, 2-chloro DMSP, dimethylsulfonioacetate, choline-o-sulfate and glycine betaine) was determined by incubating the enzyme solution with the individual analog (final concentration $20 \mathrm{mM}$ ) for $10 \mathrm{~min}$ at 20 or $25^{\circ} \mathrm{C}$ for Phaeocystis antarctica or $P$. globosa, respectively. After a $10 \mathrm{~min}$ pre-incubation with the DMSP analog, the lyase enzyme activity was determined for each sample through the addition of $5 \mathrm{mM}$ DMSP (final concentration) to the assay mixture. The enzyme activity was determined as described in the DMSP lyase assay section and com- pared to the control activity in the assay mixture without the added DMSP analog. Similarly, metal ions $\left(\mathrm{Ca}^{2+}, \mathrm{Mg}^{2+}, \mathrm{Mn}^{2+}, \mathrm{Cu}^{2+}, \mathrm{Ni}^{2+}\right)$ and several organic chemicals, EDTA, DTT (dithiothreitol), PMSF (phenylmethanesulfonylfluoride) and pCMB (parachloromercuribenzoate), were tested at 0.1 and $1.0 \mathrm{mM}$. All the metal ions were in the chloride form and analytical reagent (ACS) grade. DTT, PMSF and pCMB were molecular biology grade. Separate controls were also prepared containing either the individual metal ion or organic chemical but with no added DMSP. Assays were repeated twice $(n=2)$ and data are presented as the mean \pm SD. Differences were determined by calculating p-values using a one-tailed $t$-test (Microsoft Excel 2010).

\section{Thermodynamics of DMSP lyase}

The kinetics of thermal denaturation of DMSP lyase in extracts from both algal species were studied by incubating the enzyme solution at different temperatures $\left(20\right.$ to $35^{\circ} \mathrm{C}$ in $5^{\circ} \mathrm{C}$ increments) for $60 \mathrm{~min}$. Samples were removed at 15 min intervals, rapidly cooled in ice for $10 \mathrm{~min}$ and assayed for DMSP lyase activity using standard assay conditions (DMSP lyase assay section). The value of the first-order denaturation constant $\left(K_{\mathrm{d}}\right)$ was determined at each temperature by measuring the slope of the plot of $\ln \left(A / A_{0}\right)$ versus incubation time $(t)$, where $A_{0}=$ initial enzyme specific activity, and $A=$ measured enzyme specific activity after heat treatment. The half-life of the enzyme $\left(t_{1 / 2}, \min \right)$ was calculated using Eq. (1), assuming first-order kinetic decay:

$$
t_{1 / 2}=\ln 2 / K_{\mathrm{d}}
$$

The activation energy of denaturation $\left(E_{\mathrm{d}}\right)$ was estimated from the slope $\left(-E_{\mathrm{d}} / R\right)$ of an Arrhenius plot of $\ln \left(K_{\mathrm{d}}\right)$ versus the reciprocal of absolute temperature $\left[1 / T\left(\mathrm{~K}^{-1}\right)\right]$, where $R$ (gas constant) $=8.314 \mathrm{~J} \mathrm{~mol}^{-1} \mathrm{~K}^{-1}$. Values for changes in free energy $\left(\Delta G_{\mathrm{d}}\right)$, enthalpy $\left(\Delta H_{\mathrm{d}}\right)$ and entropy $\left(\Delta S_{\mathrm{d}}\right)$ of denaturation were determined using Eqs. (2), (3) and (4), respectively:

$$
\Delta G_{\mathrm{d}}=-R T \ln \left[\left(K_{\mathrm{d}} h\right) /\left(K_{\mathrm{b}} T\right)\right]
$$

where $h$ (Planck constant) $=6.626 \times 10^{-34} \mathrm{~J} \mathrm{~s}$, and $K_{\mathrm{b}}$ (Boltzmann constant) $=1.381 \times 10^{-23} \mathrm{~J} \mathrm{~K}^{-1}$.

$$
\begin{gathered}
\Delta H_{\mathrm{d}}=E_{\mathrm{d}}-R T \\
\Delta S_{\mathrm{d}}=\left(\Delta H_{\mathrm{d}}-\Delta G_{\mathrm{d}}\right) / T
\end{gathered}
$$

All kinetics measurements were performed twice and the mean values are reported. In all cases, SDs of the mean values were $<15 \%$. 


\section{RESULTS AND DISCUSSION}

The Phaeocystis cultures we used contained bacteria, but at relatively low abundances; $2.36 \pm 0.19 \times$ $10^{5}$ cells ml ${ }^{-1}$ and $2.45 \pm 0.22 \times 10^{4}$ cells ml $^{-1}$ in the $<1.2 \mu \mathrm{m}$ size fractions (GF/C filtrate) of the P. globosa and $P$. antarctica cultures, respectively. The DMSP lyase activities were compared between the particles retained on GF/C filters $\left(>1.2 \mu \mathrm{m}_{\text {i }}\right.$ phytoplankton fraction) and those passing through the GF/C and subsequently retained on a $0.22 \mu \mathrm{m}$ filter (bacterial fraction). For the P. globosa culture, the activity in the phytoplankton fraction was $17.3 \pm 0.94 \mathrm{nmol} \mathrm{min}{ }^{-1}$ $\mathrm{ml}^{-1}$ whereas it was $0.33 \pm 0.02 \mathrm{nmol} \mathrm{min}^{-1} \mathrm{ml}^{-1}$ in the bacterial fraction. For the $P$. antarctica culture, the values were $19.7 \pm 2.06$ and $0.29 \pm 0.014 \mathrm{nmol} \mathrm{min}{ }^{-1}$ $\mathrm{ml}^{-1}$ in the phytoplankton fraction and the bacterial fraction, respectively. Thus, $>98 \%$ of the DMSP lyase activity was associated with the phytoplankton cells. This finding is consistent with previous studies that have shown that the majority of DMSP lyase activity is associated with phytoplankton size classes in seawater and phytoplankton cultures (Steinke et al. 2002, Yost \& Mitchelmore 2009, Harada \& Kiene 2012). While some bacteria may have been attached to the Phaeocystis cells, our preliminary studies on the de novo peptide sequencing of the partially purified Phaeocystis DMSP lyases indicated lack of homology with the 6 known proteins of bacterial DMSP lyases (B. R. Mohapatra et al. unpubl. data). Thus, the extracted lyase activities that we report on below are likely to reflect those of the Phaeocystis enzymes.

The effect of $\mathrm{pH}$ on the DMSP lyase activity in extracts from Phaeocystis globosa and P. antarctica indicated that the enzymes of both algal species retained $>70 \%$ of the maximum enzyme activity over a broad $\mathrm{pH}$ range (4.0 to 7.5 ) (Fig. 1). The optimum $\mathrm{pH}$ of the lyase activity was clearly acidic and nearly the same for both species, with an optimum rate at pH 4 for P. globosa $(11.7 \pm 1.66 \mathrm{U})$ and $\mathrm{pH} 5$ for $P$. antarctica $(19 \pm 2.7 \mathrm{U})$ at $30^{\circ} \mathrm{C}$ and $20^{\circ} \mathrm{C}$, respectively. The optimum pHs observed here are much lower than the $\mathrm{pH} 10.5$ optimum reported for Phaeocystis sp. strain K (likely P. globosa) by Stefels \& Dijkhuizen (1996), but are within the range of that previously reported for in vitro DMSP lyase activity in other prymnesiophyte extracts, including 3 different strains of Gephyrocapsa oceanica (pH 5) (Franklin et al. 2010) and 4 strains of Emiliania huxleyi (pH 4 to 6) (Steinke et al. 1998, 2000). The lyases from P. globosa and $P$. antarctica also had lower $\mathrm{pH}$ optima than found in the green macroalga Ulva curvata $(\mathrm{pH}$ ) (de

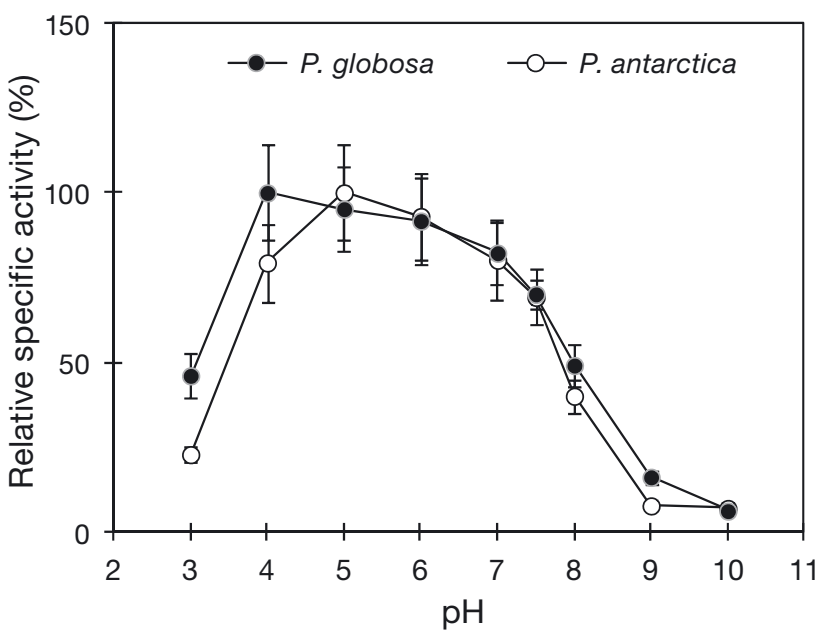

Fig. 1. Phaeocystis globosa and P. antarctica. Effect of $\mathrm{pH}$ on DMSP lyase activity (mean $\pm \mathrm{SD}, \mathrm{n}=2$ ). Relative specific activity of $100 \%=11.7 \pm 1.66$ and $18.9 \pm 2.7 \mathrm{nmol} \mathrm{DMS} \mathrm{min}{ }^{-1}$ mg protein ${ }^{-1}$ for $P$. globosa and $P$. antarctica, respectively

Souza et al. 1996), or in the bacteria Roseovarius nubinhibens (pH 6) (Kirkwood et al. 2010) and Alcaligenes sp. strain M3A (pH 8) (de Souza \& Yoch 1995a). For the Phaeocystis strains studied here, DMSP lyase activity declined substantially at assay $\mathrm{pHs}>7.5$, and at $\mathrm{pH} 9$ the activity was diminished by $>80 \%$ from the optimum.

Results of the $\mathrm{pH}$ stability study, in which the DMSP lyase enzyme was exposed to a test $\mathrm{pH}$ for $15 \mathrm{~min}$, then returned to its optimum $\mathrm{pH}$, revealed that the enzymes of both Phaeocystis globosa and $P$. antarctica were relatively stable in the $\mathrm{pH}$ range between 4 and 7.5 , returning to $>70 \%$ of maximum activity after exposure to a sub-optimal $\mathrm{pH}$. The stability test also showed that lyase activity was lost rapidly at pH 3 (>60\% loss) and above pH 8 (>80\% loss), and the loss in activity at these or other pHs was not recovered when the assay solution $\mathrm{pH}$ was returned to the optimal pH (Fig. 2).

Collectively, the results of the $\mathrm{pH}$ tests suggest that the DMSP lyase enzymes in Phaeocystis globosa and $P$. antarctica function optimally at the low $\mathrm{pH}$ characteristic of some intracellular environments (e.g. secretory vesicles, chloroplast lumen) rather than the cell surface environment exposed to seawater $(\mathrm{pH} \sim 8)$. Relatively little is known about the cellular location of DMSP lyases in algae or their physiological functions. Recently it was found that acidification of seawater or culture samples containing colonial Phaeocystis sp. to $\mathrm{pH} \sim 1$ caused rapid losses of intracellular DMSP through conversion to DMS (del Valle et al. 2011). The authors concluded that DMSP lyases remained 


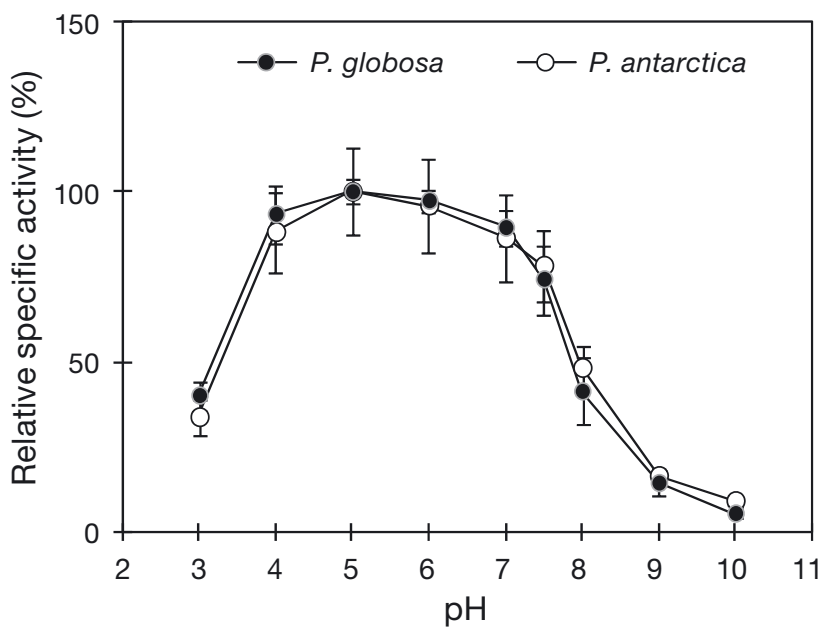

Fig. 2. Phaeocystis globosa and P. antarctica. pH stability study of DMSP lyase (mean $\pm \mathrm{SD}, \mathrm{n}=2$ ). $\mathrm{pH}$ stability tests were carried out by pre-incubation of the DMSP lyase solution at 20 ( $P$. antarctica) or $25^{\circ} \mathrm{C}(P$. globosa) in buffers at different $\mathrm{pHs}$ ranging from 3 to 10 for $15 \mathrm{~min}$. The reaction mixture was then returned to $\mathrm{pH} 4$ ( $P$. globosa) and $5(P$. antarctica), and the DMSP lyase activity was assayed. Relative specific activity of $100 \%=11.3 \pm 0.42$ and $18.2 \pm$ 2.34 nmol DMS min $^{-1} \mathrm{mg}$ protein ${ }^{-1}$ for P. globosa and $P$. antarctica, respectively

active for several minutes following acidification before being inactivated by the low $\mathrm{pH}(\sim 1)$. The high tolerance towards acidity of the DMSP lyase in P. globosa and $P$. antarctica that we observed here (25 to $50 \%$ of maximum activity at $\mathrm{pH} 3$ ) is consistent with the findings of del Valle et al. (2011). Recently, Orellana et al. (2011) speculated that DMSP lyases could be present in acidic secretory vesicles of $P$. antarctica, where both DMSP and DMS are associated with condensed polysaccharides that ultimately expand to form mucous polymers upon release to alkaline seawater. Another potential sub-cellular location with low $\mathrm{pH}$ is the chloroplast lumen. DMSP lyase has been proposed to be part of an antioxidant system in phytoplankton (Sunda et al. 2002) where cleavage of DMSP near the site of reactive oxygen species production (e.g. chloroplasts) could be beneficial to cells. It will be interesting in future work to test whether DMSP lyases are specifically adapted to function in such acidic sub-cellular locations.

DMSP lyase activity in extracts of Phaeocystis globosa and $P$. antarctica showed sharp and distinct temperature optima with maximum enzyme activities at 30 and $20^{\circ} \mathrm{C}$, respectively (Fig. 3a). At $40^{\circ} \mathrm{C}$, the DMSP lyase of P. globosa and P. antarctica exhibited only 38 and $18 \%$ of maximum enzyme activity. Nearly complete inactivation of the enzyme activity was observed above $45^{\circ} \mathrm{C}$. The activation energy of catalysis $\left(E_{\mathrm{a}}\right)$ of DMSP lyases of $P$. globosa and P. antarctica, calculated from an Arrhenius plot, were 70.1 and $71.1 \mathrm{~kJ} \mathrm{~mol}^{-1}$, respectively (Fig. 3b). Previous temperature dependence studies on the DMSP lyases of different algal and bacterial species documented variation in temperature optima. The temperature optimum was reported as 25,27 and $35^{\circ} \mathrm{C}$ for the algal species Enteromorpha clatharata (Steinke \& Kirst 1996), Cryptheocodinium cohnii (Kadota \& Ishida 1968) and Emiliania huxleyi CCMP379 (Steinke et al. 1998), respectively, and $60^{\circ} \mathrm{C}$ for the bacterium Roseovarius
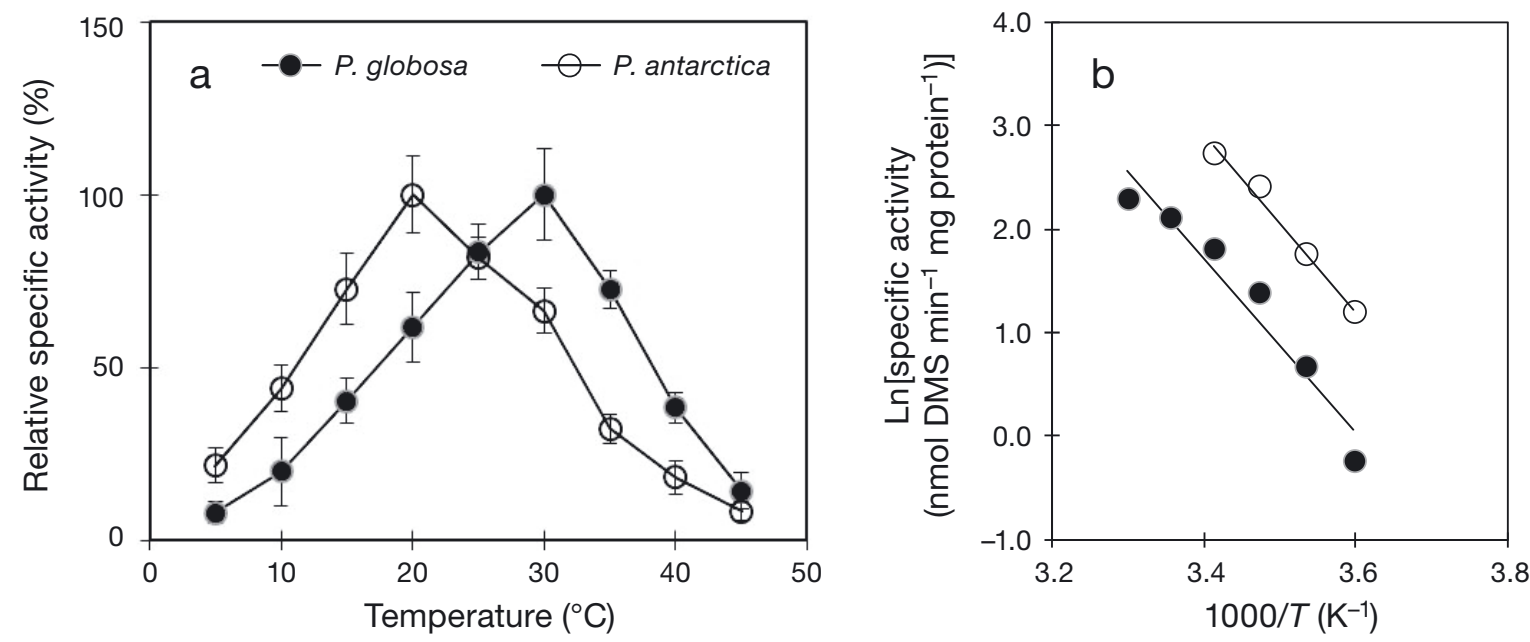

Fig. 3. Phaeocystis globosa and P. antarctica. (a) Temperature dependence of DMSP lyase activity $(m e a n \pm S D, n=2)$. Relative specific activity of $100 \%=9.86 \pm 1.31$ and $15.3 \pm 2.21 \mathrm{nmol} \mathrm{DMS} \mathrm{min}^{-1} \mathrm{mg} \mathrm{protein}^{-1}$ for $P$. globosa and $P$. antarctica, respectively. (b) Arrhenius plot for determination of the activation energy of catalysis of DMSP lyase. Lines: linear regression of mean value of duplicate measurements at different temperatures $(T)$. Linear regression analyses equations: $y=-8.42 x+30.36$, $\mathrm{r}^{2}=0.94$ for P. globosa; and $y=-8.56 \mathrm{x}+32, \mathrm{r}^{2}=0.98$ for $P$. antarctica 
nubinhibens (Kirkwood et al. 2010). The different temperature dependence of various bacterial and algal species might be attributed to differences in the phenotypic and/or genotypic traits of the organisms which are likely influenced by environmental conditions in their growth habitat. In this regard, it is not surprising that the DMSP lyase from the polar strain $P$. antarctica had a lower optimum temperature and higher activity at low temperature $\left(3.2 \pm 0.4 \mathrm{U}\right.$ at $\left.5^{\circ} \mathrm{C}\right)$ than did the temperate strain P. globosa $(0.8 \pm 0.1 \mathrm{U}$ at $\left.5^{\circ} \mathrm{C}\right)$. The observed shift to a lower temperature optimum, but with higher specific lyase activity at the lowest temperature in $P$. antarctica (natural habitat $<5^{\circ} \mathrm{C}$ ), is typical of enzyme adaptation in psychrophiles (Struvay \& Feller 2012). Thermal stability of the isolated DMSP lyase from both P. globosa and $P$. antarctica was also investigated by pre-incubation of the extracted enzyme preparations at 11 different temperatures ranging from 5 to $45^{\circ} \mathrm{C}$ in steps of $5^{\circ} \mathrm{C}$, and measuring the residual activity at the optimum temperatures of $30^{\circ} \mathrm{C}$ for P. globosa and $20^{\circ} \mathrm{C}$ for $P$. antarctica (Fig. 4). This test revealed that the DMSP lyase of P. globosa was more thermostable than that of P. antarctica. At $30^{\circ} \mathrm{C}$, the P. globosa lyase retained 89 $\pm 13 \%$ of its enzyme activity; however, only $57 \pm 9 \%$ of the $P$. antarctica DMSP lyase activity was retained at the same temperature.

The thermal denaturation process of DMSP lyase of both Phaeocystis globosa and P. antarctica followed first-order kinetics. The enzyme of $P$. globosa exhibited a $t_{1 / 2}$ of 210 and $30.1 \mathrm{~min}$ at 25 and $35^{\circ} \mathrm{C}$, respectively (Table 1). In contrast, the DMSP lyase of $P$. antarctica had a $t_{1 / 2}$ of 61.9 and $14.6 \mathrm{~min}$, respec-

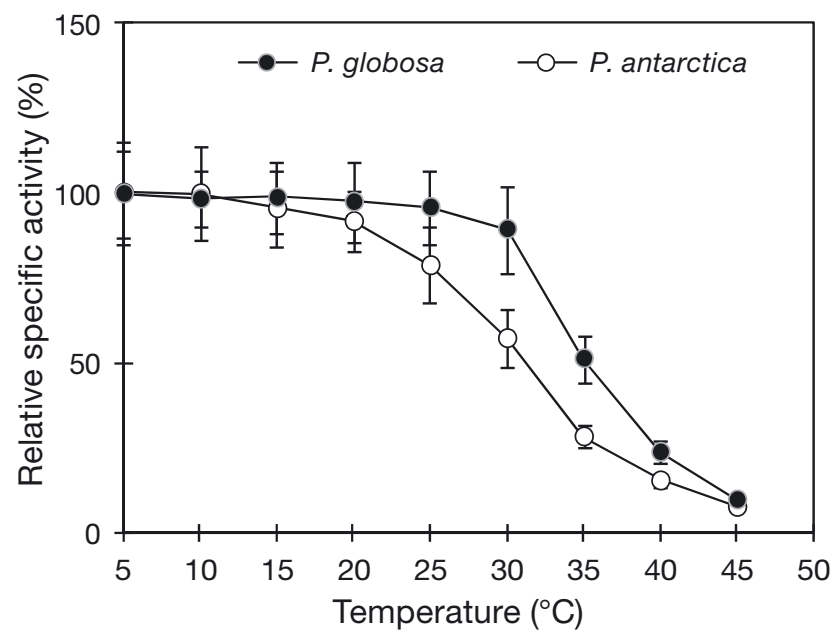

Fig. 4. Phaeocystis globosa and P. antarctica. Thermostability of DMSP lyase (mean $\pm \mathrm{SD}, \mathrm{n}=2$ ). Relative specific activity of $100 \%=8.59 \pm 1.39$ and $14.2 \pm 2.11 \mathrm{nmol} \mathrm{DMS} \mathrm{min}{ }^{-1}$ mg protein ${ }^{-1}$ for $P$. globosa and $P$. antarctica, respectively tively, at the same temperatures. The $E_{\mathrm{d}}$ of DMSP lyase was estimated from an Arrhenius plot as $135 \mathrm{~kJ}$ $\mathrm{mol}^{-1}$ for $P$. globosa and $106 \mathrm{~kJ} \mathrm{~mol}^{-1}$ for $P$. antarctica. These $t_{1 / 2}$ and $E_{\mathrm{d}}$ values suggested that the DMSP lyase of $P$. globosa was more thermostable than the $P$. antarctica lyase, again not surprising considering the polar habitat of $P$. antarctica. The $E_{\mathrm{d}}$ values were higher than the DMSP lyase $E_{\mathrm{a}}$ indicating the requirement of higher energy to initiate the thermal denaturation compared to catalysis.

In order to gain more knowledge on the mechanism of thermal denaturation of the DMSP lyase, the thermodynamic parameters such as $\Delta G_{\mathrm{d}}, \Delta H_{\mathrm{d}}$ and $\Delta S_{\mathrm{d}}$ of denaturation were determined (Table 1). The $\Delta G_{\mathrm{d}}$ and $\Delta H_{\mathrm{d}}$ values of thermal denaturation of DMSP lyase of both algal species declined with increases in temperature, suggesting a considerable change in enzyme conformation during the process of denaturation and a requirement of lesser energy to denature the enzyme at higher temperatures. Lower values of $\Delta G_{\mathrm{d}}$ and $\Delta H_{\mathrm{d}}$ for Phaeocystis antarctica lyase compared to $P$. globosa lyase indicated that the former was more thermolabile. Moreover, the positive $\Delta H_{\mathrm{d}}$ and $\Delta S_{\mathrm{d}}$ values obtained for both lyases provided supportive evidence that thermal denaturation of the enzymes is initiated by disruption of non-covalent linkages, which increases the disorder or entropy during denaturation (reviewed in Nosoh \& Sekiguchi 1990, Vieille \& Zeikus 1996). To our knowledge, the present study is the first to estimate the thermodynamic properties of DMSP lyase, and therefore it is not possible to compare our values with other studies.

We used Eadie-Hofstee plots to determine $K_{\mathrm{m}}$ and $V_{\max }$ for DMSP lyase extracted from the 2 different Phaeocystis species (data not shown). Under the opti-

Table 1. Phaeocystis globosa and P. antarctica. Half-life $\left(t_{1 / 2}\right)$ and thermodynamic parameters for denaturation of DMSP lyase at different temperatures. $\Delta G_{\mathrm{d}}$ : free energy; $\Delta H_{\mathrm{d}}$ : enthalpy; $\Delta S_{\mathrm{d}}$ : entropy of denaturation

\begin{tabular}{|lcccc|}
\hline $\begin{array}{l}\text { Species } \\
\text { Temp }\left({ }^{\circ} \mathrm{C}\right)\end{array}$ & $\begin{array}{c}t_{1 / 2} \\
(\mathrm{~min})\end{array}$ & $\begin{array}{c}\Delta G_{\mathrm{d}} \\
\left(\mathrm{kJ} \mathrm{mol}^{-1}\right)\end{array}$ & $\begin{array}{c}\Delta H_{\mathrm{d}} \\
\left(\mathrm{kJ} \mathrm{mol}^{-1}\right)\end{array}$ & $\begin{array}{c}\Delta S_{\mathrm{d}} \\
\left(\mathrm{J} \mathrm{K}^{-1} \mathrm{~mol}^{-1}\right)\end{array}$ \\
\hline $\boldsymbol{P . g l o b o s a}$ & & & & \\
20 & 462 & 87.56 & 132.80 & 154.43 \\
25 & 210 & 87.14 & 132.76 & 153.10 \\
30 & 91.2 & 86.54 & 132.72 & 152.41 \\
35 & 30.1 & 85.17 & 132.68 & 154.23 \\
& & & & \\
P. antarctica & & & & \\
20 & 116 & 84.17 & 103.15 & 64.75 \\
25 & 61.9 & 84.11 & 103.11 & 63.75 \\
30 & 26.9 & 83.47 & 103.07 & 64.67 \\
35 & 14.6 & 83.31 & 103.03 & 63.99 \\
\hline
\end{tabular}


mal assay conditions with DMSP as the substrate, the lyase of $P$. globosa $\left(\mathrm{pH} 4\right.$ and $30^{\circ} \mathrm{C}$ ) and P. antarctica (pH 5 and $20^{\circ} \mathrm{C}$ ) followed Michaelis-Menten saturation kinetics with $K_{\mathrm{m}}$ values of 1.77 and $2.31 \mathrm{mM}$ and $V_{\max }$ values of 17.3 and $28.2 \mathrm{U}$, for P. globosa and $P$. antarctica, respectively. $K_{\mathrm{m}}$ values ranging from 0.072 to $14 \mathrm{mM}$ were reported for the in vitro DMSP lyase from several algae including Phaeocystis strain K (2.25 mM) (Stefels \& Dijkhuizen 1996), Polysiphonia paniculata $(0.072 \mathrm{mM})$ (Nishiguchi \& Goff 1995) and Ulva curvata (0.52 mM) (de Souza et al. 1996), and bacteria including Alcaligenes sp. (1.4 mM) (de Souza \& Yoch 1995a) and Roseovarius nubinhibens (13.8 $\pm 5.5 \mathrm{mM}$ ) (Kirkwood et al. 2010). Intracellular DMSP concentrations in Phaeocystis sp. are typically in the 100 to $300 \mathrm{mM}$ range (Stefels \& van Leeuwe 1998). These concentrations are well above the $K_{\mathrm{m}}$ values that we determined, suggesting that lyase activity in Phaeocystis sp. could operate close to saturation in vivo if the enzyme is exposed to those high intracellular concentrations. But evidence from several studies suggests that in vivo lyase activity operates well below maximal potential activity in healthy phytoplankton cells (Wolfe \& Steinke 1996, Wolfe et al. 2002, Harada et al. 2004), indicating that lyase activity must be regulated within the cells. Unfortunately, the mechanism of DMSP lyase regulation remains largely unknown, although factors such as grazing-induced cell disruptions, high light exposure and oxidative stress have been suggested to up-regulate lyase activity (Wolfe \& Steinke 1996, Sunda et al. 2002, Galí et al. 2011).

The presence of $\mathrm{NaCl}$ affected DMSP lyase activity similarly for both Phaeocystis globosa and P. antarctica (Fig. 5). Optimal catalytic activity was found at 0.34 and $0.43 \mathrm{M} \mathrm{NaCl}$ for P. globosa and P. antarctica DMSP lyases, respectively (Fig. 5). For comparison, seawater with a salinity of $35 \mathrm{ppt}$ has a $\mathrm{NaCl}$ concentration of $\sim 0.5 \mathrm{M}$. Above $0.6 \mathrm{M}$ the lyase activity sharply declined and the enzyme lost $>50 \%$ of the activity. The optimal $\mathrm{NaCl}$ concentrations for DMSP lyase in vitro activity in the 2 Phaeocystis species was similar to that of several different strains of the prymnesiophyte Emiliania huxleyi $(0.5$ to $1.0 \mathrm{M} \mathrm{NaCl}$ for CCMP 370,379 , 1516; Steinke et al. 1998), but much higher than found for the macroalgae Enteromorpha clatharata $(0.075 \mathrm{M}$ $\mathrm{NaCl}_{i}$ Steinke \& Kirst 1996) and Ulva curvata $(0.075 \mathrm{M} \mathrm{NaCl}$; de Souza et al. 1996).
The relative catalytic efficacy of DMSP lyase isolated from Phaeocystis globosa and P. antarctica was assessed against different DMSP analogs (Table 2). For both organisms, the DMSP lyase activity was not significantly inhibited by $20 \mathrm{mM}$ 2-methyl-DMSP $(80.9 \pm 8.9$ and $89.1 \pm 10.1 \%$ of the control, with $\mathrm{p}=$ 0.114 and 0.210 , for P. globosa and P. antarctica, respectively), but was partially inhibited by 2 -chloroDMSP $(57.9 \pm 8$ and $78.2 \pm 7.1 \%$ of the control, with $\mathrm{p}=0.003$ and 0.013 , for P. globosa and P. antarctica, respectively). Choline- $O$-sulfate was strongly inhibitory to lyase activity in both species (5.3 to $7.09 \%$ of controls, $p<0.029$ ). Dimethylsulfonioacetate, one carbon shorter than DMSP, had no significant effect on lyase activity. Glycine betaine, a compound known to inhibit transmembrane transport of DMSP in marine bacteria (Kiene 1998), did not inhibit DMSP lyase

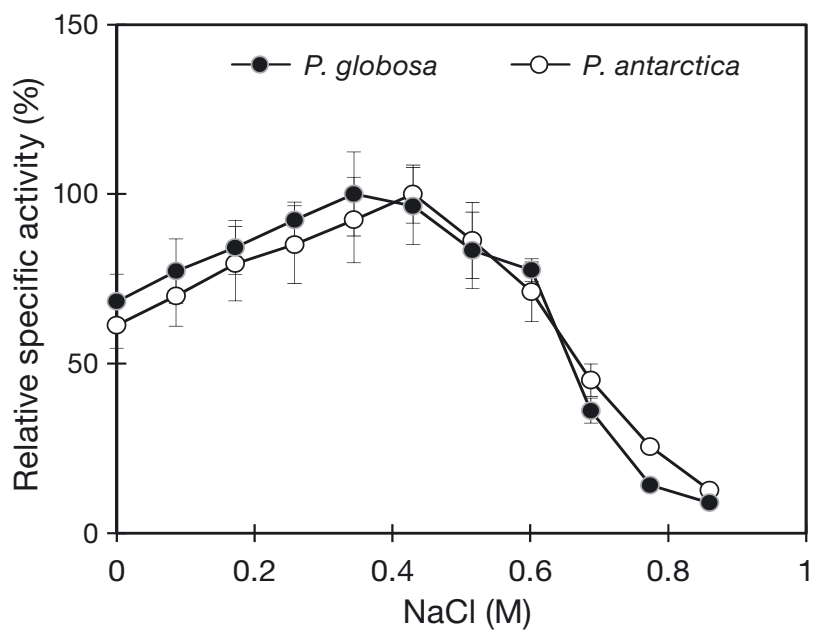

Fig. 5. Phaeocystis globosa and P. antarctica. Effect of $\mathrm{NaCl}$ concentration on DMSP lyase activity (mean $\pm \mathrm{SD}, \mathrm{n}=2$ ). Relative specific activity of $100 \%=11.9 \pm 1.48$ and $22.6 \pm 1.93$ nmol DMS min ${ }^{-1} \mathrm{mg}_{\text {protein }}{ }^{-1}$ for P. globosa and P. antarctica, respectively

Table 2. Phaeocystis globosa and P. antarctica. Effect of various DMSP analogs on DMSP lyase activity expressed as a percentage of the activity retained when DMSP was added to the assay mixtures lacking the DMSP analog. DMSP analogs $(20 \mathrm{mM})$ were pre-incubated in the DMSP lyase assay mixture from $P$. globosa or $P$. antarctica for $10 \mathrm{~min}$ at 25 and $20^{\circ} \mathrm{C}$, respectively. The residual enzyme activity was subsequently assayed with $5 \mathrm{mM}$ DMSP as the substrate

\begin{tabular}{|lllll|}
\hline DMSP analog & $\begin{array}{c}\text { P. globosa } \\
(\%)\end{array}$ & $\mathrm{p}$ & $\begin{array}{c}\text { P. antarctica } \\
(\%)\end{array}$ & $\mathrm{p}$ \\
\hline 2-methyl-DMSP & $80.9 \pm 8.9$ & 0.114 & $89.2 \pm 10.1$ & 0.210 \\
2-chloro-DMSP & $57.9 \pm 8$ & 0.035 & $78.2 \pm 7.1$ & 0.086 \\
Dimethylsulfonioacetate & $91.7 \pm 12.4$ & 0.284 & $93.5 \pm 13.2$ & 0.326 \\
Choline- $\boldsymbol{O}$-sulfate & $45.3 \pm 6.6$ & 0.026 & $51.2 \pm 6$ & 0.029 \\
Glycine betaine & $95.5 \pm 10.7$ & 0.366 & $94.3 \pm 4$ & 0.305 \\
\hline
\end{tabular}


activity appreciably, a result consistent with previous findings in bacteria (de Souza \& Yoch 1995b). Bacic \& Yoch (1998) observed induction of in vivo DMSP lyase activity in the fungus Fusarium lateritium by choline, glycine betaine and dimethylglycine, but no induction by dimethylselenoniumpropionate (DMSeP). We did not test specifically for induction of DMSP lyase activity in the Phaeocystis species, but we observed lyase activity in all $P$. globosa and $P$. antarctica cultures tested suggesting it is present at relatively high levels under the growth conditions we used.

The effect of various metal ions and organic chemicals on the extracted DMSP lyases were studied for both algal species (Table 3). DMSP lyase activities from both Phaeocystis species were not affected by the major divalent cations present in seawater, $\mathrm{Ca}^{2+}$ and $\mathrm{Mg}^{2+}{ }^{2}$; however, the activities were strongly inhibited by $\mathrm{Cu}^{2+}, \mathrm{Mn}^{2+}$ and $\mathrm{Ni}^{2+}$. The metal chelating agent, EDTA, also inhibited lyase activity, suggesting that the extracted DMSP lyases of both the algal species were metalloenzymes. Additionally, inhibition of the lyase activity by PMSF and pCMB points towards the participation of both serine and sulfhydryl (-SH) groups, respectively, at the active site of the enzyme. The thiol binding reagent $\mathrm{pCMB}$ has been used previously to inhibit DMSP lyase activity in Phaeocystis sp. (Stefels \& Dijkhuizen 1996, del Valle et al. 2011). The non-inhibition of enzyme activity by DTT provided additional evidence of the involvement of an -SH group at the active site as suggested by Stefels \& Dijkhuizen (1996). Metal ion and inhibitor studies have also been performed for DMSP lyases isolated from other algal and bacterial species. The proteins of bacterial DMSP lyase, DddL, DddQ and DddW contain metal binding cupin pock- ets (Curson et al. 2008, Todd et al. 2011, 2012). However, the DddP protein of the bacterium Roseovarius nubinhibens was not affected by EDTA, indicating no requirement of a metal cofactor for DMSP lyase activity (Kirkwood et al. 2010). It was reported that the in vitro DMSP lyase activity in the alga Polysiphonia paniculata (Nishiguchi \& Goff 1995) was partially inhibited by EDTA, PMSF and pCMB, and was not affected by $\mathrm{Ca}^{2+}$ and $\mathrm{Mg}^{2+}$, similar to what we found with the 2 Phaeocystis species.

In conclusion, the DMSP lyases extracted from mesophilic Phaeocystis globosa and psychrophilic $P$. antarctica showed very similar functional characteristics. The main differences were lower $\mathrm{pH}$ optimum in P. globosa ( $\mathrm{pH} 4)$ compared to P. antarctica (pH 5) and higher temperature optimum (and thermal stability) in P. globosa compared to $P$. antarctica. Further structural and genetic characterization will be required to determine the homology of the DMSP lyase of these 2 algal species. The DMSP lyases from the 2 Phaeocystis species tested function optimally at acidic $\mathrm{pH}$ and this is similar to what has been shown previously for several other prymnesiophytes. This raises the possibility that DMSP lyase in these organisms is adapted to function in a locally-acidic environment, but further work will be needed to determine the in vivo location and physiological function of DMSP lyase in these organisms. Our study has added important new information about the functional characteristics of DMSP lyase in Phaeocystis species that are globally important contributors to DMSP and DMS production in temperate and polar oceans. Future studies of DMSP lyase will benefit from purification of the enzyme and identification of gene(s) encoding these proteins.

Table 3. Phaeocystis globosa and $P$. antarctica. Effect of different metal ions and organic chemicals on DMSP lyase activity expressed as \% enzyme activity retained. Individual metal ions or organic compounds, at either 0.1 or $1.0 \mathrm{mM}$, were preincubated with the DMSP lyase assay mixture from P. globosa or P. antarctica for 10 min at 25 and $20^{\circ} \mathrm{C}$, respectively. The residual enzyme activity was subsequently assayed with $5 \mathrm{mM}$ DMSP as substrate. DTT: dithiothreitol; pCMB: parachloromercuribenzoate; PMSF: phenylmethanesulfonylflouride

\begin{tabular}{|c|c|c|c|c|c|c|c|c|}
\hline \multirow{2}{*}{$\begin{array}{l}\text { Metal ions and } \\
\text { chemicals }\end{array}$} & \multicolumn{4}{|c|}{ - P. globosa } & \multicolumn{4}{|c|}{ - P. antarctica } \\
\hline & $\begin{array}{c}0.1 \mathrm{mM} \\
(\%)\end{array}$ & $\mathrm{p}$ & $\begin{array}{c}1 \mathrm{mM} \\
(\%)\end{array}$ & $\mathrm{p}$ & $\begin{array}{c}0.1 \mathrm{mM} \\
(\%)\end{array}$ & $\mathrm{p}$ & $\begin{array}{c}1 \mathrm{mM} \\
(\%)\end{array}$ & $\mathrm{p}$ \\
\hline $\mathrm{Ca}^{2+}$ & $98.2 \pm 12.4$ & 0.445 & $108 \pm 11$ & 0.253 & $104 \pm 13$ & 0.373 & $97.2 \pm 11$ & 0.397 \\
\hline $\mathrm{Cu}^{2+}$ & $56.4 \pm 6.8$ & 0.023 & $9.1 \pm 0.9$ & 0.024 & $78.3 \pm 7.7$ & 0.054 & $27.2 \pm 7.7$ & 0.006 \\
\hline $\mathrm{Mg}^{2+}$ & $100 \pm 11$ & 0.500 & $104 \pm 13$ & 0.376 & $100 \pm 12$ & 0.499 & $95.1 \pm 4.1$ & 0.271 \\
\hline $\mathrm{Mn}^{2+}$ & $42.3 \pm 4$ & 0.024 & $23.2 \pm 2.7$ & 0.022 & $58.2 \pm 8.4$ & 0.018 & $36.1 \pm 5.2$ & 0.009 \\
\hline $\mathrm{Ni}^{2+}$ & $54.1 \pm 5.9$ & 0.024 & $27.1 \pm 7.5$ & 0.009 & $72.2 \pm 5.9$ & 0.034 & $48.2 \pm 7.4$ & 0.029 \\
\hline EDTA & $13.5 \pm 1.1$ & 0.024 & $10.5 \pm 1.3$ & 0.023 & $22.1 \pm 2.8$ & 0.014 & $16.3 \pm 2.1$ & 0.016 \\
\hline DTT & $103 \pm 10$ & 0.389 & $97.6 \pm 8.5$ & 0.412 & $110 \pm 9$ & 0.176 & $107 \pm 8$ & 0.239 \\
\hline pCMB & $18.2 \pm 2.4$ & 0.022 & $9.2 \pm 1.4$ & 0.023 & $26.1 \pm 3.6$ & 0.012 & $14.2 \pm 1.2$ & 0.019 \\
\hline PMSF & $18.3 \pm 2.4$ & 0.023 & $10.3 \pm 1.3$ & 0.023 & $29.1 \pm 3.8$ & 0.012 & $16.3 \pm 1.7$ & 0.018 \\
\hline
\end{tabular}


Acknowledgements. This work was funded by grants from the National Science Foundation (OPP-09-44686 to D.J.K. and OPP-09-44659 to R.P.K.). We thank B. Taylor for the kind gift of 2-methyl-DMSP and 2-chloro-DMSP. We also thank A. Hanson for providing choline- $o$-sulfate. We thank L. Oswald for general assistance in the laboratory.

\section{LITERATURE CITED}

Arrigo KR, Robinson DH, Worthen DL, Dunbar RB, DiTullio GR, VanWoert M, Lizotte MP (1999) Phytoplankton community structure and the drawdown of nutrients and $\mathrm{CO}_{2}$ in the Southern Ocean. Science 283:365-367

> Bacic MK, Yoch DC (1998) In vivo characterization of dimethylsulfoniopropionate lyase in the fungus Fusarium lateritium. Appl Environ Microbiol 64:106-111

> Charlson RJ, Lovelock JE, Andreae MO, Warren SG (1987) Oceanic phytoplankton, atmospheric sulphur, cloud albedo and climate. Nature 326:655-661

Curson ARJ, Rogers R, Todd JD, Brearley CA, Johnston AWB (2008) Molecular genetic analysis of a dimethylsulfoniopropionate lyase that liberates the climate changing gas dimethylsulfide in several marine alpha-proteobacteria and Rhodobacter sphaeroides. Environ Microbiol 10:757-767

> Curson ARJ, Todd JD, Sullivan MJ, Johnston AWB (2011) Catabolism of dimethylsulfoniopropionate: microorganisms, enzymes and genes. Nat Rev Microbiol 9:849-859

de Souza MP, Yoch D (1995a) Purification and characterization of dimethylsulfoniopropionate lyase from an alcaligenes-like dimethyl sulfide-producing marine isolate. Appl Environ Microbiol 61:21-26

de Souza MP, Yoch D (1995b) Comparative physiology of dimethylsulfide production by dimethylsulfoniopropionate lyase in Pseudomonas doudoroffii and Alcaligenes sp. strain M3A. Appl Environ Microbiol 61:3986-3991

> de Souza MP, Chen YP, Yoch DC (1996) Dimethylsulfoniopropionate lyase from the marine macroalga Ulva curvata: purification and characterization of the enzyme. Planta 199:433-438

del Valle DA, Slezak D, Smith CM, Rellinger AN, Kieber DJ, Kiene RP (2011) Effect of acidification on preservation of DMSP in seawater and phytoplankton cultures: evidence for rapid loss and cleavage of DMSP in samples containing Phaeocystis sp. Mar Chem 124:57-67

> Dickson DMJ, Kirst GO (1987) Osmotic adjustment in marine eukaryotic algae: the role of inorganic ions, quaternary ammonium, tertiary sulphonium and carbohydrate solutes. New Phytol 106:645-655

DiTullio GR, Jones DR, Geesey ME (2003) Dimethylsulfide dynamics in the Ross Sea during austral summer. In: DiTullio GR, Dunbar RB (eds) Biogeochemistry of the Ross Sea. AGU Antarct Res Ser 78:279-294

- Franklin DJ, Steinke M, Young J, Probert I, Malin G (2010) Dimethylsulfoniopropionate (DMSP), DMSP-lyase activity (DLA) and dimethylsulphide (DMS) in 10 species of coccolithophore. Mar Ecol Prog Ser 410:13-23

Galí M, Saló V, Almeda R, Calbet A, Simó R (2011) Stimulation of gross dimethylsulfide (DMS) production by solar radiation. Geophys Res Lett 38, doi:10.1029/2011GL 048051

Guillard RRL (1975) Culture of phytoplankton for feeding marine invertebrates. In: Smith WL, Chanley MH (eds) Culture of marine invertebrate animals. Plenum Press,
New York, NY, p 26-60

Harada H, Kiene RP (2012) Assessment and characteristics of DMSP lyase activity in seawater and phytoplankton cultures. Publ Seto Mar Biol Lab 41:1-16

- Harada H, Rouse MA, Sunda W, Kiene RP (2004) Latitudinal and vertical distributions of particle-associated dimethylsulfoniopropionate (DMSP) lyase activity in the western North Atlantic Ocean. Can J Fish Aquat Sci 61:700-711

Ishida Y (1968) Physiological studies on evolution of dimethylsulfide from unicellular marine algae. Mem Coll Agric Kyoto Univ 94:47-82

- Kadota H, Ishida Y (1968) Effect of salts on enzymatical production of dimethyl sulfide from Gyrodinium cohnii. Bull Jpn Soc Sci Fish 34:512-518

Karsten U, Kuck K, Vogt C, Kirst GO (1996) Dimethylsulfoniopropionate production in phototrophic organisms and its physiological function as a cryoprotectant. In: Kiene RP, Visscher PT, Keller MD, Kirst GO (eds) Biological and environmental chemistry of DMSP and related sulfonium compounds. Plenum, New York, NY, p 143-153

Keller MD, Bellows WK, Guillard RRL (1989) Dimethyl sulfide production in marine phytoplankton. In: Saltzmann ED, Cooper WJ (eds) Biogenic sulfur in the environment. Am Chem Soc, Washington, DC, p 167-182

Kiene RP (1998) Uptake of choline and its conversion to glycine betaine by bacteria in estuarine waters. Appl Environ Microbiol 64:1045-1051

Kirkwood M, Le Brun NE, Todd JD, Johnston AWB (2010) The dddP gene of Roseovarius nubinhibens encodes a novel lyase that cleaves dimethylsulfoniopropionate into acrylate plus dimethyl sulfide. Microbiology 156:1900-1906

> Kirst GO, Thiel C, Wolff H, Nothnagel J, Wanzek M, Ulmke R (1991) Dimethylsulfoniopropionate (DMSP) in ice-algae and its possible biological role. Mar Chem 35:381-388

> Moran MA, Reisch CR, Kiene RP, Whitman WB (2012) Genomic insights into bacterial DMSP transformations. Annu Rev Mar Sci 4:523-542

> Niki T, Kunugi M, Otsuki A (2000) DMSP lyase activity in five marine phytoplankton species: its potential importance in DMS production. Mar Biol 136:759-764

- Nishiguchi MK, Goff LJ (1995) Isolation, purification, and characterization of DMSP lyase (dimethylpropiothetin dethiomethylase [4.4.1.3]) from the red alga Polysiphonia paniculata. J Phycol 31:567-574

> Nosoh Y, Sekiguchi T (1990) Protein engineering for thermostability. Trends Biotechnol 8:16-20

Orellana MV, Matrai PA, Janer M, Rauschenberg CD (2011) Dimethylsulfoniopropionate storage in Phaeocystis (Prymnesiophyceae) secretory vesicles. J Phycol 47: 112-117

Parsons TR, Maita Y, Lalli CM (1984) Plant pigments. In: Parsons TR, Maita Y, Lalli CM (eds) A manual of chemical and biological methods for seawater analysis. Pergamon Press, Oxford, p 99-112

Porter KG, Feig YS (1980) The use of DAPI for identifying and counting aquatic microflora. Limnol Ocenogr 25: 943-948

> Reisch CR, Stoudemayer MJ, Varaljay VA, Amster IJ, Moran MA, Whitman WB (2011) Novel pathway for assimilation of dimethylsulphoniopropionate widespread in marine bacteria. Nature 473:208-211

Rellinger AN, Kiene RP, del Valle DA, Kieber DJ and others (2009) Occurrence and turnover of DMSP and DMS in the deep waters of the Ross Sea, Antarctica. Deep-Sea Res I 56:686-702 
Schoemann V, Becquevort S, Stefels J, Rousseau V, Lancelot C (2005) Phaeocystis blooms in the global ocean and their controlling mechanisms: a review. J Sea Res 53:43-66

Simó R (2001) Production of atmospheric sulfur by oceanic plankton: biogeochemical, ecological and evolutionary links. Trends Ecol Evol 16:287-294

Stefels J (2000) Physiological aspects of the production and conversion of DMSP in marine algae and higher plants. J Sea Res 43:183-197

Stefels J, Dijkhuizen L (1996) Characteristics of DMSP-lyase in Phaeocystis sp. (Prymnesiophyceae). Mar Ecol Prog Ser 131:307-313

Stefels J, van Boekel WHM (1993) Production of DMS from dissolved DMSP in axenic cultures of the marine phytoplankton species Phaeocystis sp. Mar Ecol Prog Ser 97: 11-18

Stefels J, van Leeuwe MA (1998) Effect of iron and light stress on the biochemical composition of Antarctic Phaeocystis sp. (Prymnesiophyceae). I. Intracellular DMSP concentrations. J Phycol 34:486-495

Stefels J, Dijkhuizen L, Gieskes WWC (1995) DMSP-lyase activity in a spring phytoplankton bloom off the Dutch coast, related to Phaeocystis sp. abundance. Mar Ecol Prog Ser 123:235-243

Steinke M, Kirst GO (1996) Enzymatic cleavage of dimethylsulfoniopropionate (DMSP) in cell-free extracts of the marine macroalga Enteromorpha clathrata (Roth) Grev. (Ulvales, Chlorophyta). J Exp Mar Biol Ecol 201:73-85

Steinke M, Daniel C, Kirst GO (1996) DMSP lyase in marine macro- and microalgae. In: Kiene RP, Visscher PT, Keller MD, Kirst GO (eds) Biological and environmental chemistry of DMSP and related sulfonium compounds. Plenum Press, New York, NY, p 317-324

Steinke M, Wolfe GV, Kirst GO (1998) Partial characterization of dimethylsulfoniopropionate (DMSP) lyase isozymes in 6 strains of Emiliania huxleyi. Mar Ecol Prog Ser 175:215-225

Steinke M, Malin G, Turner SM, Liss PS (2000) Determination of dimethylsulfoniopropionate (DMSP) lyase activity using headspace analysis of dimethylsulphide (DMS). J Sea Res 43:233-244

Steinke M, Malin G, Archer SD, Burkill PH, Liss PS (2002) DMS production in a coccolithophorid bloom: evidence for the importance of dinoflagellate DMSP lyases. Aquat Microb Ecol 26:259-270

Struvay C, Feller G (2012) Optimization to low temperature

Editorial responsibility: Wajih A. Naqvi,

Dona Paula, India activity in psychrophilic enzymes. Int J Mol Sci 13: 11643-11665

Sunda W, Kieber DJ, Kiene RP, Huntsman S (2002) An antioxidant function for DMSP and DMS in marine algae. Nature 418:317-320

Todd JD, Rogers R, Li YG, Wexler M and others (2007) Structural and regulatory genes required to make the gas dimethylsulfide in bacteria. Science 315:666-669

> Todd JD, Curson ARJ, Dupont CL, Nicholson P, Johnston AWB, Sullivan MJ, Johnston AWB (2009) The dddP gene, encoding a novel enzyme that converts dimethylsulfoniopropionate into dimethyl sulfide is widespread in ocean metagenomes and marine bacteria also occurs in some Ascomycete fungi. Environ Microbiol 11:1376-1385

> Todd JD, Curson ARJ, Kirkwood M, Sullivan MJ, Green RT, Johnston AWB (2011) DddQ, a novel, cupin-containing, dimethylsulfoniopropionate lyase in marine roseobacters and in uncultured marine bacteria. Environ Microbiol 13: 427-438

- Todd JD, Kirkwood M, Newton-Payne S, Johnston AWB (2012) DddW, a third DMSP lyase in a model Roseobacter marine bacterium, Ruegeria pomeroyi DSS-3. ISME J 6: 223-226

van Duyl FC, Gieskes WWC, Kop AJ, Lewis WE (1998) Biological control of short-term variations in the concentration of DMSP and DMS during a Phaeocystis spring bloom. J Sea Res 40:221-231

> Vieille C, Zeikus JG (1996) Thermozymes: identifying molecular determinants of protein structural and functional stability. Trends Biotechnol 14:183-190

Wolfe GV, Steinke M (1996) Grazing-activated production of dimethyl sulfide (DMS) by two clones of Emiliania huxleyi. Limnol Oceanogr 41:1151-1160

Wolfe GV, Strom SL, Holmes JL, Radzio T, Olson MB (2002) Dimethylsulfoniopropionate cleavage by marine phytoplankton in response to mechanical, chemical, or dark stress. J Phycol 38:948-960

> Yost DM, Mitchelmore CL (2009) Dimethylsulfoniopropionate (DMSP) lyase activity in different strains of the symbiotic alga Symbiodinium microadriaticum. Mar Ecol Prog Ser 386:61-70

Zingone A, Chrétiennot-Dinet MJ, Lange M, Medlin L (1999) Morphological and genetic characterization of Phaeocystis cordata and P. jahnii (Prymnesiophyceae), two new species from the Mediterranean Sea. J Phycol 35:1322-1337

Submitted: July 23, 2012; Accepted: February 24, 2013 Proofs received from author(s): April 23, 2013 